\title{
Cearenses "indolentes" na transição do trabalho escravo para o trabalho livre (1888-1900)
}

\author{
"Lazy" people of Ceará in transition from slavery to free labor \\ (1888-1900) \\ Edgar Braga Neto* \\ https://orcid.org/0000-0002-3232-1779
}

\begin{abstract}
Resumo
A transição do trabalho escravo para o trabalho livre está além de ser um processo histórico simples, restrito ao preconceito com o trabalhador nacional eà vinda de imigrantes europeus. Neste artigo, demonstramos que existe uma longa disputa entre as oligarquias do Sul e as do Norte pelos trabalhadores do Ceará - os "indolentes" cearenses, como os definem na época. Ao dominarem o Estado, as oligarquias do Sul subsidiam a viagem desses trabalhadores para as fazendas de café, por intermédio da verba dos socorros públicos, que é destinada às vítimas da seca. Assim, vamos problematizar a teoria do gerenciamento da população brasileira, mediante essa evidência, baseada, neste artigo, em pesquisa histórica; e, também, demonstrar que o racismo das elites é acessório a seus interesses econômicos.
\end{abstract}

Palavras-chave: Migração. Racismo. Oligarquias

\begin{abstract}
The transition from slave to free labor is far from a simple historical process restricted to the prejudice against the national worker and to the arrival of European immigrants. In this article, we show that there is a long dispute between the South and North oligarchies to dominate the workers from Ceará - known as "Cearense indolente". Once dominating the State, South oligarchies subsidize the transfer of these workers to the coffee plantations, through the grant of public aid, which is intended for the victims of the drought. Therefore, we discuss the theory of the management of the Brazilian population using this evidence, which is based on historical research; and also demonstrate that the racism of elites is less important than their economic interests.
\end{abstract}

Keywords: Migration. Racism. Oligarchies

\footnotetext{
* Doutor em Sociologia pela Universidade Federal do Ceará. Professor de História da Coordenação de Ciências Humanas/Sociologia da Universidade Federal do Maranhão. E-mail: edgarbraganeto@gmail.com
} 


\section{Introdução}

Neste artigo, discutimos a disputa entre as oligarquias do Sul e do Ceará pelos retirantes cearenses no processo histórico de transição do trabalho escravo para o trabalho livre. Devido às grandes secas do final do século XIX, os trabalhadores cearenses, desocupados em razão dessa intempérie, vão trabalhar nos cafezais, em substituição aos escravos. Através de sua presença na economia cafeeira, refletimos sobre o racismo de nossas elites, cujos limites não excluem os cearenses "indolentes", e, ainda, por que o problema da mão de obra não se resolve com os trabalhadores nacionais.

Em nossa análise, a tensão entre as oligarquias sobre o destino dos retirantes cearenses está circunscrita entre 1888 e 1900, período esse marcado por duas grandes secas. Em cada seca, ocorre uma disputa pela mão de obra dos retirantes entre as oligarquias do Sul e as do Ceará. As oligarquias do Ceará buscando reter a população de retirantes. E as do Sul querendo transportá-los para sua região, mais precisamente, para as fazendas de café. Dos 70 mil cearenses que migraram, 20 mil foram para o Sul, o que demonstra que, apesar das perdas, as elites do Ceará conseguiram impedir que eles fossem tão somente para o Sul, ou seja, não se acovardaram perante a poderosa classe dos cafeicultores. ${ }^{1}$ A partir de nossas fontes, temos como acompanhar essa contenda pelos trabalhadores nacionais, numa conjuntura em que, apesar da abolição da escravatura, a imigração europeia ainda não tinha se consolidado.

\section{Racismo das elites?}

Com o processo de abolição da escravatura avançando, no último quartel do século XIX, era preciso substituir o braço escravo pelo trabalhador nacional que estava espalhado pelo país (ver as resoluções dos congressos agrícolas), porém essa solução não era vista com bons olhos pelas elites econômicas, sobretudo pelos intelectuais urbanos, que eram adeptos das teorias racistas. Eles classificavam os trabalhadores nacionais de forma aviltante, chamando-os de "incautos", "viciados", "mestiços", "inaptos", "inconscientes”, "desanimados", "inexpertos”, “apáticos”, "indolentes”, "vadios”, "imprevidentes" etc. Essa desclassificação fazia parte de "calúnias que acionam os sentimentos de vergonha ou culpa do próprio grupo socialmente inferior,

\footnotetext{
${ }^{1}$ Neste artigo, adotamos no texto as regiões geográficas da época, isto é: Norte e Sul. Por isso, o leitor vai estranhar quando chamarmos a região cafeeira de Sul e o semiárido de Norte, o que equivaleria hoje ao Sudeste e Nordeste, respectivamente. Mesmo assim, decidimos por adotar as regiões geográficas da época, tal como está nas fontes.
} 
diante de símbolos de inferioridade e sinais de caráter imprestável", que são atribuídos pelos grupos socialmente dominantes (elites econômicas), com o intuito de manter sua dominação e superioridade em relação aos socialmente inferiores (trabalhadores nacionais). ${ }^{2}$

Nesse sentido, a classe produtora se encontrava sob um dilema. Por um lado, estava sendo forçada a abolir a escravidão, e, por outro, ela não confiava nos trabalhadores nacionais para tornar os seus negócios mais competitivos no sistema econômico da época. Contudo, era preciso resolver tal dilema, pois os negócios do café poderiam fracassar, não por uma intempérie, mas pela falta de trabalhadores. Assim, enquanto os cafeicultores organizavam a forma de trazer os imigrantes europeus para suas fazendas, eles aproveitaram a seca do Norte, a grande oferta de mão de obra desocupada, para deslocar os "mestiços" do Ceará para o Sul cafeicultor.

Mas, ao serem contratados para o trabalho nas fazendas de café, os cearenses não estavam livres das calúnias relativas ao trabalhador nacional; pelo contrário, eles eram considerados, sobretudo, como "imprevidentes" e "indolentes", por causa da falta de preparo para resistir aos longos estios que devastavam a sua terra natal. Para os intelectuais, a imprevidência dos trabalhadores rurais era uma das causas diretas do fenômeno da seca. Sobrinho, por exemplo, não eximiu os "incautos" sertanejos cearenses da responsabilidade pelas secas. Em suas palavras: "Nenhuma providencia, nenhuma medida para evitar a repetição de tão negras misérias, preocupa o espírito trêfego dos que já as sofreram". 3 Já os parlamentares, que eram contrários à emigração de cearenses para o Sul, davam-lhes ainda, conforme o racismo da época, o ímpeto de "indolentes".

Indolentes eram os trabalhadores indesejados, que não se encaixavam no modelo branco-europeu. Esse conceito classificava dos chins aos cearenses (trabalhadores livres nacionais), que foram desqualificados pelos intelectuais racistas e principalmente pelos políticos que lucravam com a viagem dos imigrantes europeus. Essa classificação vinha de longa data: na sociedade escravista colonial, de formação social polarizada entre senhores e escravos, os homens pobres livres, que estavam deslocados, eram considerados

\footnotetext{
${ }^{2}$ Sobre essa desclassificação social, ver ELIAS, Norbert; SCOTSON, John L. Os Estabelecidos e os outsiders: sociologia das relações de poder a partir de uma pequena comunidade. Tradução de Vera Ribeiro. Rio de Janeiro: Jorge Zahar Ed., 2000, p. 131.

${ }^{3}$ SOBRINHO, Thomaz Pompeu. O Problema das Sêcas no Ceará. $2^{a}$ edição, Editores Gadelha S. Filho, 1920, p. 17.

${ }^{4}$ Ver: GONÇALVES, Paulo Cesar. Migração e mão de obra: retirantes cearenses na economia cafeeira do Centro-Sul (1877-1901). São Paulo: Editora Humanitas, 2006.
} 
"indolentes". ${ }^{5}$ Ao dizer que tais trabalhadores eram "preguiçosos", "desleixados" e "negligentes", certos parlamentares exaltavam os europeus, porque a vinda deles para a América beneficiava o lobby das empresas de navegação às quais estavam ligados.

Além do fator da mestiçagem, que tornava os cearenses "inaptos" para assumir a missão de embranquecer o país no lugar dos brancos europeus, os cearenses eram tidos como "indolentes", especialmente devido à pobreza de sua terra. No século XIX, ao percorrer o Ceará, o missionário Daniel Kidder disse que, em tal província, "já existia suficiente indolência" e que seria "excesso de crueldade escravizar um povo para se abandonarem os cearenses a ociosidade ainda maior". ${ }^{6}$ Para o inspetor da Inspetoria de Obras Contra as Secas (IOCS), Aarão Reis, uma das dificuldades para encetar os trabalhos do órgão no Norte semiárido era a natural indolência da população dessa zona. ${ }^{7}$ Assim tal classificação era comum, principalmente no século XIX e começo do século XX.

Todavia, apesar de serem considerados “indolentes", os cearenses eram contratados para o trabalho nas fazendas de café, juntamente com os europeus que vinham para embranquecer a população (conforme a tese do branqueamento). Um exemplo disso está no personagem Felicíssimo, do romance Canaã, que, juntamente com imigrantes alemães, vai trabalhar nas fazendas de café da província do Espírito Santo. ${ }^{8}$ Os cafeicultores assim contratavam, além dos alemães, italianos e poloneses, os "mestiços" cearenses. Tal ação dos cafeicultores não contradiz o pensamento racista, ou a tese imigrantista, que apregoa a vinda dos brancos europeus para o país e que tem como objetivo salvar a nação brasileira da mestiçagem degenerativa? Até que ponto o racismo das elites inviabilizava o trabalhador nacional no contexto da transição do trabalho escravo para o trabalho livre?

Tudo leva a crer que o racismo das elites tem limites bem demarcados, sobretudo quando os seus negócios estavam em causa. Dizemos isso porque o trabalhador livre nacional, considerado "indolente", foi utilizado como

\footnotetext{
${ }^{5}$ SOUZA, Laura de Mello e. Desclassificados do ouro: a pobreza mineira no século XVII. 3 edição, Rio de Janeiro: Graal, 1986.

${ }^{6}$ KIDDER, Daniel P. Reminiscências de viagens e permanência nas províncias do norte do Brasil: compreendo notícias históricas e geográficas do império e de diversas províncias. Belo Horizonte: Ed. Itatiaia; SP: USP, 1980, p. 141.

${ }^{7}$ BRASIL. Inspetoria de Obras Contra as Secas. Relatórios dos trabalhos executados durante o anno de 1913, Rio de Janeiro: Imprensa Nacional, 1914, p. 13.

${ }^{8}$ ARANHA, Graça. Canaã. Rio de Janeiro: Nova Fronteira, 1981. Canaã foi publicado, pela primeira vez, em 1902.
} 
mão de obra dos grandes ciclos econômicos, inclusive em São Paulo, onde o imigrantismo era considerado como a solução mais adequada para "o país". Estamos de acordo, portanto, com Graham e Buarque de Holanda Filho (1971 apud Eisenberg, 1989), que defendem que os fazendeiros não evitaram o trabalhador nacional e que o racismo era mais disseminado pelos intelectuais urbanos, tais como Nina Rodrigues e Oliveira Viana. ${ }^{9}$

Isso não quer dizer que, nessa linha de pensamento, estaríamos reforçando a tese da democracia racial, mas, sim, que os fazendeiros estavam ávidos por mão de obra ("carvão para queimar"), independentemente de sua aparência e origem raciais. E não porque eram democratas, mas porque precisavam de trabalhadores para explorar, enquanto traziam os imigrantes europeus. Julgado "indolente", o cearense não era o trabalhador ideal que iria realizar a missão de embranquecer o país; no entanto, o que importava era que dava, perfeitamente, para explorar a sua mão de obra, tal como faziam com os escravos, nas fazendas de café.

\section{Migração cearense}

O racismo praticado pelas elites econômicas não evitou o trabalhador livre nacional, pois elas não impediram a presença dos "mestiços" do Norte nas fazendas de café. Se havia racismo da sua parte, tal atitude era contida e limitada, porque essas elites, especialmente a fazendeira, não se importavam com os "defeitos atávicos" dos trabalhadores nacionais. Elas estavam preocupadas com a colheita do café, que, para elas, podia ser colhido por mãos negras, brancas ou amarelas. Em outras palavras, tais elites queriam força de trabalho (combustível humano) para a economia do café, independentemente de qual grupo "racial" pertenciam os trabalhadores. Nesse sentido, os cafeicultores aproveitaram a valorização do café no mercado internacional para exportá-lo. ${ }^{10}$ Assim, com ou sem migração estrangeira, a rubiácea devia ser exportada, e, ao contrário das teses que redimensionam o imigracionismo, os cafeicultores do Sul tinham agentes no Norte para contratarem os trabalhadores, que não eram considerados "brancos", mas sim "mestiços".

Aliás, o principal agente dos cafeicultores era o Estado brasileiro, que instrumentalizado pela elite cafeeira, se transformava em um dos grandes

\footnotetext{
${ }^{9}$ EISENBERG, Peter L. Homens esquecidos: escravos e trabalhadores livres no Brasil, século XVIII e XIX. Campinas: Ed. Unicamp, 1989, p. 240.

${ }^{10}$ HOLlOWAY, Thomas H. Imigrantes para o café e sociedade em São Paulo. Tradução de Eglê Malheiros. Rio de Janeiro: Paz e Terra, 1984.
} 
responsáveis pela emigração de cearenses para o Sul. ${ }^{11}$ Desse modo, o Estado agia nos períodos de longas estiagens: ou seja, quando devia socorrer às vítimas da seca no Ceará. Para "socorrer" os cafeicultores, o Estado convertia os socorros públicos em passagens de navio para os retirantes da seca chegarem ao Sul. Em vez de organizar a construção de obras públicas no Ceará, para o emprego dos retirantes, como fez na seca de 1877, o Estado atuava somente no sentido de garantir passagens de navio aos retirantes, com o objetivo de transportar essa mão de obra para São Paulo, Rio de Janeiro e Espírito Santo, as províncias produtoras de café.

Se realmente houvesse restrições à incorporação dessa mão de obra mestiça no Vale do Paraíba e no Oeste paulista, o governo federal não iria subsidiar a migração interna. Após o fim do tráfico negreiro e a decadência da economia açucareira, os cafeicultores do Sul passaram, então, a buscar mão de obra no Norte, seja ela escrava, seja ela livre. Se não levarmos em conta tal fato, perdemos de vista o encontro entre os retirantes do Norte e os imigrantes europeus nas fazendas de café; além disso, defendemos que as elites brasileiras, por serem racistas, evitaram o trabalhador nacional nas lavouras; e ademais, supomos que o problema da mão de obra se restringia somente ao Sul e que, assim, o Norte também não organizou núcleos coloniais para atrair os colonos estrangeiros. Os cafeicultores souberam aproveitar as conjunturas favoráveis para alistar braços livres e escravos no Norte; e assim, durante as secas do final do século XIX e começo do século XX, puderam contar com o aparato do Estado para transferir a mão de obra dos retirantes para as fazendas.

Um exemplo disso está nas ações de Antonio da Silva Prado, um dos maiores incentivadores da imigração italiana. ${ }^{12}$ Quando ministro da Agricultura em 1888, ele lançou mão de todos os meios para transferir os cearenses para as fazendas de café no Sul, especialmente para São Paulo. Defendendo os interesses de sua classe de cafeicultor, ele deu instruções para o sobrinho Caio Prado, presidente da província do Ceará, embarcar os retirantes para as fazendas paulistas. Com efeito, na seca de 1888, a parceria entre os Prado alavancou o número de migrantes que saíram do Ceará. Nesse sentido, o fato de ter fundado a Sociedade Brasileira de Imigração não impedia Antonio Prado de incentivar a migração interna e de transportar os retirantes cearenses para o Sul, como demonstra o quadro a seguir:

\footnotetext{
${ }^{11}$ BRAGA NETO, Edgar. Emigração cearense (1888-1915): sentidos, controle e configuração social. Novas Edições Acadêmicas: Saarbrücken, 2014.

${ }^{12}$ CARONE, Edgard. A República Velha I: instituições e classes sociais (1889-1930). $4^{a}$ edição, São Paulo: Difel, 1978, p. 156.
} 
Quadro 1: Migrantes que saíram pelo porto de Fortaleza no primeiro semestre de 1889.

\begin{tabular}{|c|c|c|c|c|c|c|c|}
\hline \multirow{2}{*}{ Destino } & \multicolumn{6}{|c|}{ Ano de 1889} & \multirow[t]{2}{*}{ Total } \\
\hline & Janeiro & Fevereiro & Março & Abril & Maio & Junho & \\
\hline Alagoas & 3 & 0 & 7 & 5 & 0 & 22 & 37 \\
\hline Bahia & 2 & 0 & 27 & 6 & 4 & 2 & 41 \\
\hline Espírito Santo & 424 & 0 & 111 & 274 & 193 & 14 & 1.016 \\
\hline Minas Gerais & 0 & 0 & 1 & 0 & 0 & 0 & 1 \\
\hline Paraíba & 5 & 0 & 2 & 0 & 20 & 0 & 27 \\
\hline Pernambuco & 0 & 11 & 26 & 29 & 73 & 61 & 200 \\
\hline Rio de Janeiro & 1.385 & 71 & 1.389 & 1.743 & 641 & 576 & 5.805 \\
\hline Rio Grande do Norte & 0 & 1 & 3 & 0 & 0 & 0 & 4 \\
\hline Rio Grande do Sul & 0 & 0 & 0 & 1 & 0 & 0 & 1 \\
\hline Santa Catarina & 0 & 0 & 2 & 0 & 17 & 0 & 19 \\
\hline São Paulo & 1.212 & 13 & 187 & 243 & 89 & 265 & 1.909 \\
\hline
\end{tabular}

Fonte: CEARÁ. Relação de Emigrantes Norte-Sul (1889).

Conforme o quadro, a migração foi mais intensa para São Paulo, Rio de Janeiro e Espírito Santo, ou seja, para as províncias produtoras de café. Dos 9.052 migrantes, 8.730 seguiram para essas províncias, e, nos cinco primeiros meses de 1889, um terço do total de migrantes da seca de 1888-1889 já tinha migrado para o Sul. O destino que mais recebeu os migrantes foi o Rio de Janeiro. Como hipótese deste trabalho e tendo como base tais números, pensamos que isso se deve à situação econômica dos cafeicultores do Vale do Paraíba, que ao se encontrarem falidos em razão das dívidas contraídas e da baixa produção cafeeira na região no final do século XIX, ficaram impossibilitados para arcar com a vinda de trabalhadores europeus para as suas fazendas, pretendendo resolver o problema da falta de braços com os retirantes do Norte.

Além do papel exercido pelo Estado no fomento à migração, havia o trabalho dos agenciadores, que vinham ao Ceará, independentemente do Estado e da situação climática da província, buscar trabalhadores, com o intuito de resolver a demanda de mão de obra dos cafezais e seringais, como demonstra este quadro: 
Quadro 2: Migrantes que saíram pelo porto de Fortaleza nos vapores do Loide Brasileiro de 1892 a 1897.

\begin{tabular}{|c|c|c|c|}
\hline \multirow{2}{*}{ Ano } & \multicolumn{2}{|c|}{ Destino } & \multirow{2}{*}{$\begin{array}{c}\text { Número de } \\
\text { emigrantes }\end{array}$} \\
\cline { 2 - 3 } & Norte & Sul & 13.593 \\
\hline 1892 & 13.593 & - & 9.175 \\
\hline 1893 & 7.380 & 1.795 & 5.932 \\
\hline 1894 & 4.443 & 1.489 & 11.181 \\
\hline 1895 & 9.092 & 2.089 & 11.580 \\
\hline 1896 & 9.686 & 1.894 & 9.099 \\
\hline 1897 & 7.312 & 1.787 & 60.560 \\
\hline $1892-1897$ & 51.506 & 9.054 & \\
\hline
\end{tabular}

Fonte: Dias (1904, p. 241).13

Com o Estado e a iniciativa privada, essa corrente migratória que partia do Ceará vai ganhando força. De 1892 a 1897, migraram mais de 60 mil cearenses. Embora a migração para o Norte seja mais forte, a migração para o Sul continua sendo expressiva. Tudo leva a crer que essa diferença se deveu à ausência do governo central no translado dos cearenses para o Sul, porque, como não houve uma situação de emergência provocada pela seca nesse período, o governo central não tinha como justificar a transferência da população do Ceará para a região do seu interesse.

Portanto, ao contrário da teoria do "gerenciamento da população brasileira", a migração dos trabalhadores nacionais do Norte para o Sul também foi relevante para a economia cafeeira, especialmente no contexto da abolição da escravatura.

Todavia, apesar desses números, a imigração europeia foi capaz de encobrir a migração do trabalhador nacional, principalmente por causa do seu grande fluxo. Como o número de imigrantes foi superior ao dos trabalhadores cearenses, a presença destes na economia cafeeira ficou à margem da História, restrita a poucas pesquisas, tais como: a de Denise Soares da Moura, ${ }^{14}$ a de Paulo César Gonçalves, ${ }^{15}$ e, também, a nossa (que se transformou em livro),

\footnotetext{
${ }^{13}$ Não temos o total de emigrantes, referente ao ano de 1892, que vai para o Sul; por isso, a lacuna. Tampouco temos uma especificidade maior dos locais de destino.

${ }^{14}$ MOURA, Denise Aparecida Soares da. Saindo das sombras: homens livres no declínio do escravismo. Campinas: Unicamp, 1998.

${ }^{15}$ GONÇALVES, op. cit.
} 
e que investiga as causas da emigração cearense, no final do século XIX e começo do século XX. ${ }^{16}$

Assim, por falta de fontes adequadas, alguns historiadores e cientistas sociais afirmam que os ex-escravos e os trabalhadores nacionais, "homens livres" e "libertos", não participaram da economia cafeeira, porque tal economia teve como braços apenas os imigrantes europeus. Hansebalg, por exemplo, até admite a presença de ex-escravos no decadente Vale do Paraíba, porém oculta a presença do trabalhador nacional:

Assim, no Vale do Paraíba em verdadeira decadência econômica, os ex-escravos não tiveram de competir com trabalhadores estrangeiros, como o fizeram em muitas das áreas rurais e urbanas para onde foram forçados a se dirigir. No Estado de São Paulo, em regiões onde a economia cafeeira prosperava e o trabalho estrangeiro era abundante, os fazendeiros não readmitiam os ex-escravos que tinham abandonado as fazendas e preferiram imigrantes assalariados. ${ }^{17}$

De posse de nossos dados, será que os ex-escravos não competiam com os trabalhadores livres, os "cearenses indolentes"? E, em São Paulo, embora os fazendeiros não tivessem readmitido os ex-escravos, eles só preferiam os imigrantes assalariados? Assim, Hansebalg redimensiona o "deslocamento socioeconômico da população de cor", excluindo o trabalhador nacional e reforçando a tese do imigrantismo.

Nessa mesma linha de pensamento, Davis, embora seja mais radical, porque acredita na "eugenia positiva" da República, diz que: "Os cafeicultores do sudeste, da sua parte, só queriam trabalhadores estrangeiros 'brancos' após a Abolição, logo fizeram disso a política federal da nova República". ${ }^{18}$ Ao contrário disso, como demonstramos, os cafeicultores não criavam obstáculos para receber os retirantes, os mestiços do Norte, em suas propriedades.

Já Morales acredita que, além do "deslocamento socioeconômico da população de cor", há um verdadeiro "gerenciamento da população brasileira", chegando a afirmar que os cafeicultores não tinham agenciadores de mão de obra no Ceará:

\footnotetext{
${ }^{16}$ BRAGA NETO, op. cit.

${ }^{17}$ HASENBALG, Carlos. Discriminação e desigualdades raciais no Brasil. $2^{\mathrm{a}}$ edição. Belo Horizonte: Editora UFMG; Rio de Janeiro: IUPERG, 2005, p.171.

${ }^{18}$ DAVIS, Mike. Holocaustos coloniais. Tradução de Alda Porto. Rio de Janeiro: Record, 2002, p. 394, grifo do autor.
} 
Não era do interesse dos cafeicultores a presença desse indivíduo considerado biologicamente inapto para funcionar numa economia de base capitalista. Isso sugere que estava em jogo não apenas uma localização diferencial de trabalhadores mas sim um gerenciamento da população brasileira na qual as variáveis raça e região eram estrategicamente articuladas e construíam a desigualdade no país. ${ }^{19}$

Dessa forma, Morales não consulta as fontes históricas do período, pois os cafeicultores tinham interesse em trazer os "inaptos” cearenses para suas fazendas: tanto que contavam com agenciadores no Ceará para realizar essa tarefa e, também, com um agente mais robusto: o Estado. Através dele, os cafeicultores conseguiram levar os cearenses para as fazendas de café. Desse modo, as variáveis "raça" e "região" não eram "estrategicamente articuladas"; e o café, principal produto econômico do país, deveria ser exportado, não obstante a abolição da escravatura.

Portanto, pensamos que o número superior de europeus em relação ao de migrantes nacionais na economia cafeeira, e a criação de uma identidade paulista calcada somente no imigrante, dissimularam a migração de cearenses para os cafezais do Sul no século XIX. Nesse sentido, concordamos com Moura e Paiva, que afirmam que a entrada nos cafezais de migrantes nacionais foi contemporânea à entrada de imigrantes europeus. ${ }^{20}$

\section{Oligarquias contra oligarquias: a seca de 1888}

Com a incidência do fenômeno das secas no Ceará e, por conseguinte, os auxílios do governo central para combatê-lo, teve início a prática de subvenção das passagens de navio aos retirantes cearenses. Instrumentalizado pelos cafeicultores paulistas e premido pelo contexto da abolição, o Estado queria solucionar o problema do Ceará transferindo a mão de obra ociosa das secas para as fazendas de produção do Sul, ou seja, para onde havia necessidade urgente de braços. Assim, a economia do Ceará era atingida duas vezes: a primeira, pela seca, que esterilizava a terra; a segunda, pelo Estado, que lhe subtraía a mão de obra existente.

\footnotetext{
${ }^{19}$ MORALES, Lúcia Arrais. Vai e vem, vira e volta: as rotas dos soldados da borracha. São Paulo: Annablume; Fortaleza: SECULT, 2002, p. 87.

${ }^{20}$ PAIVA, Oldair da Cruz; MOURA, Soraya. Hospedaria de imigrantes de São Paulo. São Paulo: Paz e Terra, 2008, p. 65-66.
} 
Assim, no final do século XIX e começo do século XX, especialmente após o boom do algodão, o Ceará se encontrava numa grave crise econômica, em razão das grandes estiagens e, por consequência, da emigração subsidiada com a verba dos socorros públicos, ou com incentivos vindos dos estados amazônicos, que precisavam garantir mão de obra para a economia da borracha. Assim, as tradicionais redes sociais entre proprietários de terra e trabalhadores rurais estavam sendo desestruturadas. Se a subvenção das passagens continuasse a ser concedida como socorro público, os coronéis e fazendeiros perderiam seus trabalhadores, os famigerados moradores. Desse modo, a economia e o capital político estavam em disputa. Ao deixarem escapar os trabalhadores, os latifundiários ficavam enfraquecidos, perdendo o domínio tradicional que tinham sob essa população miserável. ${ }^{21}$ Portanto, se a oferta de mão de obra era decisiva para a manutenção dos interesses econômicos e sociais dos latifundiários pecuaristas do Norte, eles deviam agir como classe, ao defender tal oferta das mãos dos cafeicultores.

Em 1889 (ainda no Império), com a morte de Caio Prado, presidente do Ceará e grande incentivador da migração de retirantes para o Sul, a oligarquia cafeeira perdeu seu maior aliado no Norte. Quem o substituiu na presidência foi o senador Henrique D’Ávila, do Rio Grande do Sul. Ao assumir em setembro desse ano, Henrique D'Ávila encontrou a economia do Ceará exaurida em virtude de dois anos de seca, necessitando da ajuda do governo central para prestar socorro à população. Entretanto, o governo central só se manifestava através do pagamento de passagens de navio aos retirantes, para eles seguirem para o Sul do país, onde não havia seca, mas sim uma economia pujante que necessitava de braços.

Melhor oportunidade não havia para a classe dirigente da economia cafeeira, pois a maioria dos retirantes estava concentrada no litoral à espera dos socorros públicos e, desse modo, seria fácil conduzi-los para o Sul. Além disso, a emigração subvencionada dissiparia, em parte, a desconfiança que os políticos do Sul tinham sobre a apropriação indevida das verbas públicas contra as secas, a famosa "indústria da seca", realizada pelas classes dirigentes da região Norte.

Todavia, o governo central não esperava a resistência do presidente Henrique D’Ávila em retirar a população da zona da seca. Como não tinha ligações com o Ceará, tudo indica que essa atitude de fixar a população rural

${ }^{21}$ Ver: BARREIRA, César. Trilhas e atalhos do poder. Rio de Janeiro: Rio Fundo, 1992. 
se tratava da oposição que as demais oligarquias realizavam contra a toda poderosa oligarquia paulista.

Assim, Henrique D’Ávila não foi o primeiro a ser contrário à emigração subsidiada pelo governo central. Na seca de 1877-1879, diversos grupos também se levantaram contra a realização dessa ação. Agora, não podemos deixar de registrar a coragem que ele teve para desobedecer às ordens do governo central. Seus argumentos contra as medidas tomadas para promover a migração serviram para a elaboração de um discurso a favor da fixação da população no Ceará. Dentre esses argumentos, para barrar mais essa peça de instrumentalização do Estado pela oligarquia paulista, havia o da diferença de custos entre a migração subsidiada e os socorros destinados a manter as populações em seus locais de origem:

Não era possível manter esse serviço nessas condições de tão elevados sacrifícios do Thesouro Nacional, porque, dentro de pouco tempo, toda a receita do Imperio não bastaria para satisfazer as exigencias da secca do Ceará. ${ }^{22}$

No entanto, o governo central ignorava a contabilidade do presidente do Ceará. Ele não se preocupava com os vultosos gastos que fazia para manter a migração, pois essas despesas seriam partilhadas com as províncias, e os lucros, advindos dessa mão de obra, divididos apenas com os cafeicultores do Sul. E assim, ele continuava com a emigração subsidiada: "Governo julga conveniente de preferência outras medidas concessão de passagens dos retirantes".23

Por que o governo central se interessava em manter a emigração dos retirantes, se, conforme o presidente do Ceará, ela onerava os cofres públicos? Ora, estamos no final do ano de 1888, somente seis meses após a Abolição, período esse que a imigração europeia não estava consolidada, e, portanto, a disponibilidade de mão de obra dos retirantes para os cafeicultores se mostrava como uma possibilidade real de organizar as suas relações de produção. Mas, o presidente do Ceará percebia essa manobra dos cafeicultores e aproveitava a sua posição de presidente da província para estorvar o plano deles.

Com efeito, o governo central não tinha na presidência do Ceará um presidente obediente a seus desígnios. Em apenas três meses de governo, Henrique D’Ávila encerrou a migração dos retirantes, porque, para ele, essa

\footnotetext{
${ }^{22}$ CEARÁ. Mensagem do presidente Henrique D'Ávila, em 9 de setembro de 1889, p. 4-5.

${ }^{23}$ BRASIL. Secretaria da Agricultura. Telegrama destinado ao Governo da Província do Ceará. Rio de Janeiro, 1888.
} 
migração e o trabalho nas obras públicas prejudicavam ainda mais a população faminta. Nesse sentido, ele defendia que apenas a distribuição de alimentos nas comarcas da província poderia dar condições reais para os retirantes famintos retomarem ao trabalho agrícola no inverno:

Levei o socorro publico a todas as comarcas da Provincia, creando um comissariado geral em cada uma delas, e dividindo-as em tantos comissarados locaes quantos fossem as circunscripções de raio de circunferência de 4 a 5 legoas que existirem em cada uma delas. Em todos esses pontos coloquei armazéns de gêneros alimentícios ficando o central a cargo do commissario geral, e os locaes dirigidos pelos comissarios locaes. ${ }^{24}$

Essa medida tinha como objetivo manter os trabalhadores em suas comarcas, evitando assim a continuidade dos deslocamentos do interior para o litoral, como desejava o governo central, ou melhor, os cafeicultores. Desse modo, o presidente da província preferia levar os socorros públicos aos lares dos sertanejos a empregá-los numa obra pública, cujo número de operários que suportava era inferior ao número empregado pela necessidade do momento, e, além disso, criava vícios e trabalho imaginário. ${ }^{25}$

Ele contrariava, então, a política de socorros públicos do governo central. Claro que, por trás dele, estavam as oligarquias do Ceará, interessadas em barrar a migração. De qualquer modo, lutar contra os cafeicultores não era tarefa fácil: era ter contra si uma poderosa classe econômica que já dirigia os negócios do Estado no ocaso do Império. Nessa luta, o lado mais fraco, a província do Ceará, representada pelo seu presidente, não suportava a pressão da classe cafeicultora. E assim, terminaram os três meses do governo de Henrique D’Ávila, nos quais ele tentava fixar a população sertaneja, resistindo à pressão da Secretaria de Agricultura:

Resta-me desejar a V. Exc. mais felicidades do que me coube por sorte, nas relações com o Governo Central, que, ainda escravizado ao centralizador systema que tem tornado rachitico este grande império, continua a considerar as Presidencias das Provincias meros accrescimos de suas secretarias. ${ }^{26}$

\footnotetext{
${ }^{24}$ CEARÁ. Mensagem do Presidente do Ceará Henrique D'Ávila, em 9 de setembro de 1889, p. 4.

${ }^{25}$ Rodolfo Teófilo também era contrário à construção de grandes açudes, pelos mesmos motivos alegados por Henrique D'ávila. TEÓFILO, Rodolfo. História da Secca do Ceará (1877 a 1880). Fortaleza: Typographia do Libertador, 1883, p. 494.

${ }^{26}$ CEARÁ. Mensagem do Presidente do Ceará Henrique D’Ávila, em 9 de setembro de 1889, p. 8.
} 
Logo após a sua saída da presidência do Ceará, o Império caía devido a uma aliança política entre os militares e cafeicultores. Com isso, era instaurada a República. Mas, apesar do sistema republicano, não se modificavam as condições de vida das massas rurais, ou seja, continuavam precárias. ${ }^{27}$ Como tais condições não eram alteradas, os sertanejos permaneciam em uma situação vulnerável, e a solução republicana para o problema da seca foi a mesma do Império: manter a emigração subvencionada para o Sul (apenas com o surgimento da Inspetoria de Obras Contra as Secas, em 1909, haverá uma mudança significativa na política das secas). Agora, o sistema republicano dava mais espaço para as demais oligarquias agrárias disputarem o poder, como as que estavam ligadas com o binômio gado-algodão.

\section{Oligarquias contra oligarquias: a seca de 1900}

Em 1900, o Ceará era atingido por mais uma seca, e, por isso, os fluxos migratórios ganhavam impulso. Mais uma vez, o Estado do Ceará tinha que recorrer ao governo federal para debelar a crise econômica causada pela intempérie. Assim, também, em 1900, houve uma série de desacordos entre o governo do Ceará e governo federal, entre as oligarquias agrárias, em torno do destino dos sertanejos. Por um lado, o governo federal tinha como presidente Manoel Ferraz de Campos Sales, um dos maiores cafeicultores do país, e que, por isso, desejava reverter a proteção social dada ao Ceará em passagens de navio aos retirantes. Por outro, o governo do Ceará, juntamente com seus aliados no Congresso e grupos da sociedade civil, pretendiam a todo custo manter os retirantes nas plagas cearenses.

Mesmo com a adoção da República federativa, os estados (as antigas províncias) continuavam sem autonomia para adotar medidas que o governo central reprovava, e que era preciso respeitar o compromisso entre eles firmado, conhecido por "política dos Governadores". ${ }^{28}$ Por isso, o governo do Ceará se encontrava em maus lençóis, porquanto necessitava do governo federal, mas não podia aceitar que os socorros públicos fossem empregados para subsidiar a migração dos retirantes porque, desse modo, tal contingente

\footnotetext{
${ }^{27}$ COSTA. Da Monarquia à República: momentos decisivos. 9 ed. São Paulo: Editora Unesp, 2010, p. 492.

${ }_{28}$ "O acordo foi consagrado em 1900, durante o reconhecimento de poderes da nova legislatura. Por ele, presumia-se a legitimidade dos deputados eleitos pelas políticas dominantes nos estados, conseguindo assim o apoio dessas políticas para a ação do governo federal". In: CARVALHO, José Murilo de. Os bestializados: 0 Rio de Janeiro e a República que não foi. São Paulo, Companhia das Letras, 1987, p. 32.

Ver também: FAORO, Raymundo. Os donos do poder: formação do patronato brasileiro. $4^{\mathrm{a}}$ ed. São Paulo: Globo, 2008, p. 640-647; CARONE, Edgard. A República Velha II... op. cit., p. 192-202.
} 
de mão de obra desfalcaria as fazendas do Ceará. As oligarquias de São Paulo, as mais poderosas do ponto de vista econômico, não iam perder a oportunidade de retirar os cearenses do seu solo natal. E as oligarquias do Ceará não estavam dispostas a aceitar essa situação, porque, além da força de trabalho, perderiam o voto dos trabalhadores rurais que, com a instauração da República, se tornara essencial para a conservação do coronelismo. ${ }^{29}$ Tal rivalidade entre as oligarquias não era estranha ao cenário da República Velha, no qual "as oligarquias que dominavam nos vários estados lutavam entre si no plano federal, onde frequentemente se opunham à oligarquia paulista". ${ }^{30}$

Foi através de uma carta oficial destinada ao presidente da República, em 26 de julho de 1900, que o governador do Ceará, Pedro Borges, apresentou um plano de combate à seca no qual a emigração entrava como "medida provisória" e a construção de obras públicas no Ceará, como "medida definitiva". Segundo Borges, o que importava eram as "medidas definitivas", ou seja: a construção de açudes e o prolongamento das estradas de ferro. Consoante com tal plano, o deputado federal Francisco Sá submeteu à Câmara dos Deputados, em 12 de setembro desse ano, projeto de combate à seca que previa $10 \mathrm{mil}$ contos de réis para socorrer os retirantes do Norte por meio de obras de utilidade pública. Enquanto o projeto tramitava pelo Congresso Nacional, o governo estadual devia se contentar com a execução da "medida provisória". O problema foi que o projeto de Francisco Sá, que ajudaria a conter mais a população, não foi votado: "Entravado com emendas a sua passagem na Camara, [...] não teve esse projecto o curso rápido que a situação, já desesperadora, das classes desfavorecidas estava a reclamar com imprescindível urgência". ${ }^{31}$

Pressionado pela classe fazendeira do Ceará, Borges pediu então ajuda à Presidência da República, à Câmara e ao Senado, para construir obras públicas, com o intuito de empregar milhares de braços que estavam desocupados por causa da esterilidade da terra. Além disso, lembrava que o governo federal só tinha se manifestado em favor da migração, facilitando a retirada da população, ou seja: o despovoamento do Ceará. Lembrava ainda que o Estado do Ceará não podia enfrentar sozinho tal calamidade, e que, portanto, a ajuda

29 “[...] a abolição do regime servil e, depois, com a República, a extensão do direito de sufrágio deram importância fundamental ao voto dos trabalhadores rurais. Cresceu, portanto, a influência política dos donos de terra, devido à dependência dessa parcela do eleitorado, consequência direta da nossa estrutura agrária, que mantém os trabalhadores da roça em lamentável situação de incultura e abandono". In: LEAL, Victor Nunes. Coronelismo, enxada e voto: o município e o regime representativo no Brasil. $7^{\mathrm{a}}$ edição. São Paulo: Companhia das Letras, 2002, p. 232.

${ }^{30}$ COSTA, op. cit., p. 399.

${ }^{31}$ CEARÁ. Mensagem do Governador do Ceará, Pedro Augusto Borges, em 1 de julho de 1901, p. 34. 
da União para construir obras públicas se fazia necessária. Nesse sentido, tal ajuda não deve se traduzir em emigração subvencionada, pois assim o governo federal estaria intervindo nos negócios peculiares do Ceará.

Com a aprovação do projeto de Francisco Sá, sem as emendas que o modificariam, na sessão de 3 de outubro da Câmara, a representação cearense ficou confiante na vitória da luta travada com os cafeicultores. Desse modo, o Ceará poderia contar com verbas suficientes para construir açudes e estradas com a mão de obra dos retirantes, e não vê-los migrar.

Porém, ao passar pelo Senado em 9 de outubro, o projeto foi modificado: a comissão de finanças ignorou "a parte essencial" dele, ou seja, "a execução de serviços ou obras de utilidade geral”, obedecendo assim à Presidência da República:

Obtidos os esclarecimentos prestados pelo governo, e conhecida sua opinião sobre o magno assumpto, a comissão de finanças do Senado apresentou o seu parecer, consoante os motivos expostos na informação do governo, e segundo o qual o socorro a prestar devia cingir-se a emigração dos cearenses! De sorte que a comissão alterou o projecto vindo da Camara, eliminando a sua parte essencial, no tocante a salutar providencia da execução de serviços ou obras de utilidade geral. ${ }^{32}$

De fato, os interesses dos latifundiários pecuaristas eram derrotados no Senado. Mas, da mesma forma que fez Henrique D’Ávila, o presidente Borges, os representantes do Ceará e o Centro Cearense do Rio não cruzaram os braços e assistiram passivamente à ida de milhares de trabalhadores para o Sul do país. Conforme disse Furtado, fizeram "uma campanha em grande escala para obstruir a execução do mesmo". ${ }^{33}$

Embora já tivessem criado uma estrutura responsável pela vinda dos imigrantes, os cafeicultores continuavam a instrumentalizar o Estado, com o propósito de deslocar os retirantes para a colheita de café. Por isso, a tensão entre os cafeicultores e latifundiários pecuaristas em torno da mão de obra dos retirantes estava tão latente, que o governo do Ceará preferia perder mão de obra para Amazonas e Pará do que para São Paulo, alegando que tinha "maior afinidade de interesses" com os estados amazônicos, e que o cearense se "adaptava" mais ao clima da floresta (ver a mensagem do Governador Pedro Augusto Borges de 1901).

\footnotetext{
${ }^{32}$ Idem, p. 36.

${ }^{33}$ FURTADO, Celso. Formação econômica do Brasil. São Paulo: Companhia das Letras, 2009, p.191.
} 
Essa tensão que esquentava o clima do parlamento não surtia o efeito desejado pelas oligarquias do Norte, pois o presidente da República, Campos Sales, continuava com seu plano:

[...] que seria de vantagem encaminhar a população da zona rural onde a seca se manifestou para regiões de outros Estados que oferecessem condições para permitir utilizar a aptidão dos migrantes em trabalhos produtivos. Para este fim conviria que o Congresso Nacional habilitasse o governo com os recursos necessários. ${ }^{34}$

Como Campos Sales teimava em não direcionar as verbas para a construção de obras públicas no Ceará, Borges lhe enviou mais um telegrama, no dia 17 de outubro. Nele, Borges demonstrava total consonância com os discursos do ex-presidente do Ceará, Henrique D’Ávila, pois afirmava que a emigração exigia mais verbas dos cofres públicos do que construir obras nos territórios atingidos pela seca. Ele ressaltou ainda que, desde 26 de julho, o seu pedido foi no sentido de executar as "medidas definitivas", e não as "medidas provisórias".

Em resposta, Campos Sales, extremamente ofendido com a pressão social que sofria, escreveu em 18 de outubro:

Resta chamar vossa atenção para a atitude de alguns reclamantes altamente inconveniente no momento em que deve ser guardada a necessária serenidade para que possam agir de harmonia os poderes federaes e estadoaes, que terão de combinar sua acção, afim de tornal-a benéfica, pois estou bem convencido de que em nosso conceito não é só a União que cabe responder por esta angustiosa situação, que me aflige o espirito profundamente em véspera de uma viagem a que me obrigaram superiores interesses nacionais. ${ }^{35}$

A réplica de Borges não demorou, e, no dia seguinte (19 de outubro), respondeu ao presidente:

o Ceará sabe compartilhar das glorias e revezes do Brasil; nunca exigirá além dos recursos d'este, mas sentiria o abandono em que traduziu a prestação de socorros restringida à emigração. ${ }^{36}$

\footnotetext{
${ }^{34}$ Da mensagem de 10 de outubro de 1900 de Manoel Ferraz de Campos Sales apud FROTA, Luciara Silveira de Aragão e. Documentação oral e temática da seca: estudos. Brasília: Centro Gráfico, Senado Federal, 1985, p. 179. ${ }^{35}$ CEARÁ. Mensagem do Governador Pedro Augusto Borges, em 1 de julho de 1901, p. 38.

${ }^{36}$ Idem, p. 38.
} 
O presidente do Ceará denunciava, então, o governo federal. Campo Sales queria, a todo custo, transferir a mão de obra dos retirantes para os cafezais, demonstrando que não se preocupava com os efeitos da seca no Ceará. A sua preocupação era com café, que era maior fonte de divisas do país. Quanto maior oferta de trabalhadores, melhor para a economia cafeeira, que podia assim rebaixar os salários. Foi, portanto, através do café que ele pretendia restabelecer o crédito que, após as guerras civis de 1893-1895, estava em baixa. ${ }^{37}$ Convinha a Campos Sales a tarefa de desenvolver a economia e restabelecer a confiança dos investidores. ${ }^{38}$

Desse modo, a miséria que acometia o Ceará não sensibilizava Campos Sales, que estava preocupado com os negócios do café. Enquanto havia desacordo entre o governo do Ceará e governo federal, os retirantes eram os que mais sofriam, com a demora no combate à seca. Sem recurso alimentar, eles apelavam para as raízes venenosas. Agora, nessa seca, surgiam inúmeros pombais, que eram por eles aproveitados em sua alimentação. ${ }^{39}$ Dessa forma, eles realmente tinham que contar com os parcos recursos da zona seca, uma vez que os governos federal e estadual não concordavam sobre o seu destino.

A principal divergência entre tais governos estava na migração subvencionada dos retirantes. Nesse sentido, Borges argumentou que a emigração só beneficiava as empresas de navegação e os estados que recebiam os braços desocupados; que esses braços constituíam capital ao estado assolado pela seca e, portanto, a migração deles o prejudicava; e que as sociedades de destino muitas vezes não estavam preparadas para recebê-los, o que fazia com que eles enfrentassem uma situação social pior do que aquela na qual se encontravam no contexto de origem. Fazia a União, segundo Borges, um "mandato de despejo", que anulava o direito de locomoção, a liberdade do indivíduo: era, com efeito, forçar um indivíduo, que estava premido pela miséria, a aceitar o embarque como única proteção do Estado.

Nesse sentido, o governo Campos Sales era pressionado, pois não se admitia que ele utilizasse o recurso da emigração subsidiada para enriquecer os cafeicultores. Só que nessa batalha as oligarquias do Ceará não estavam sozinhas: elas contavam com a bancada cearense no Congresso Federal (Francisco

\footnotetext{
${ }^{37}$ GUANABARA, Alcindo. A presidência Campos Sales. Brasília: Senado Federal, 2002, p. 48.

38 "A necessidade de satisfazer os compromissos externos - Funding Loan - e a estabilização financeira interna, fazem com que o governo relegue a segundo plano os partidos políticos e os interesses regionais". CARONE. A República Velha II... op. cit., p. 190.

${ }^{39}$ Ver: Teófilo 1922 apud GIRÃO, Raimundo. História Econômica do Ceará. $2^{a}$ ed. Fortaleza: Casa José de Alencar, 2000 , p. 426.
} 
Sá e Waldemiro Cavalcanti na Câmara, e José Bizerril Fontenelle e Joaquim Catunda no Senado); ${ }^{40}$ com o Club de Engenharia do Rio, que entusiasmado com os empregos que surgiriam com a intervenção federal na região das secas, através da construção de obras públicas, fez questão de incentivar a ação construtora do Estado; e, com o Centro Cearense do Rio, que era formado por cearenses que residiam na capital da República e que, portanto, fazia pressão para que as verbas contra as secas fossem aproveitadas para a abertura de estradas e o represamento de águas no Ceará. Foi somente através dessa rede que as oligarquias do Ceará conseguiram que o projeto de Francisco Sá passasse pelo Senado.

Todavia, esse desentendimento com a província do Ceará não fazia a oligarquia paulista desistir de subsidiar as passagens de navio aos cearenses, que eram chamados de "indolentes". Ao mesmo tempo que o governo federal dava prosseguimento à construção do açude Quixadá, que se tratava de uma "medida definitiva", ele dava ordens aos engenheiros fiscais das estradas de ferro de Baturité e de Sobral, seus representantes no Ceará, para transportar mais cearenses, nos vapores da Companhia de Navegação do Loide Brasileiro, ou seja, ele continuava incentivando a "medida provisória" do plano de combate à seca. Não obstante, Borges sentia que esse era um momento de arrefecimento da luta, e, portanto, lhe era positivo:

A emigração não foi eliminada, é certo, do plano do governo na prestação de socorros, mas não esteve sob a acção aguda dos pontos do dilema com que finalizei o meu primeiro telegrama ao Sr. Presidente da República, ou obrigada à impetuosidade de uma corrente, cujo curso impossível fôra deter. ${ }^{41}$

Desse modo, a tensão entre as oligarquias pela mão de obra dos sertanejos se repetia em todas as grandes secas do final do século XIX e começo do século XX. As oligarquias só entraram num acordo, quando a população pobre já mendigava nas estradas do interior ou nas ruas das vilas e cidades, o que contrariava a missão civilizadora da República. Aliás, o governo do cafeicultor Campos Sales, preocupado com a estabilização financeira do país e com os negócios do café, abandonou as classes trabalhadoras e a baixa classe média à própria sorte. No seu governo, "a situação das classes trabalhadoras e da baixa classe média, que sofrem com a alta excessiva dos aluguéis, com o desemprego, é desesperada". ${ }^{42}$

\footnotetext{
${ }^{40}$ SOBRINHO, Thomaz Pompeu. História das Secas (Século XX)..., op. cit., p. 194.

${ }^{41}$ CEARÁ. Mensagem do Governador Pedro Augusto Borges, em 1 de julho de 1901, p 38-39.

${ }^{42}$ CARONE. A República Velha II... op. cit., p. 210-211.
} 
Portanto, foi nas secas que os latifundiários pecuaristas podiam lutar com os cafeicultores, porque eles tinham a lei a seu favor. Foi assim que, em 1900, os latifundiários pecuaristas derrubaram a emenda que permitia ao governo federal usar os recursos somente para subsidiar a emigração, atrapalhando assim os seus negócios. Podemos dizer, então, que os latifundiários venceram essa contenda, mesmo tendo uma emigração de 40 mil cearenses na seca de 1900, pois conseguiram, ao agir como uma classe social, direcionar dois terços das verbas contra as secas para a construção de obras públicas em seu torrão natal. ${ }^{43}$ Além disso, dos 40 mil que emigraram, somente um pequeno grupo deles foi para o Sul. Agora, o estado de São Paulo se encontrava noutra conjuntura, principalmente no tocante à migração de trabalhadores europeus que vinham trabalhar nas fazendas de café, na última década do século XIX e na primeira década do século XX, fazendo com que os cafeicultores não se desgastassem perante os demais grupos econômicos que administravam grandes porções do território nacional, como o dos latifundiários pecuaristas do Ceará.

\section{Conclusão}

Após os fatos narrados, a questão central da transição do trabalho escravo para o trabalho livre nos interpele: por que não se resolveu a falta de braços com os trabalhadores nacionais? Em nosso trabalho, a resposta que mais se coaduna às fontes utilizadas foi dada por Celso Furtado. Em suas palavras: "Prevalecia no país uma atitude extremamente hostil a toda transferência interna de mão de obra, o que não é difícil de explicar, tendo em vista o poder político dos grupos cujos interesses resultariam prejudicados". ${ }^{44}$ Desse modo, foram as oligarquias do Norte, os latifundiários pecuaristas e seus representantes que impediram que a classe dos cafeicultores continuasse com a política de transferir a sua mão de obra durante as secas.

Além disso, o lobby das empresas de navegação, que fazia o translado dos imigrantes, era fortíssimo na época, fazendo com que o Estado brasileiro custeasse tal viagem para a região Sul. Isso, sem dúvida, demonstrou como os paulistas controlavam a União, apesar da resistência do Norte a esse domínio. ${ }^{45}$

Vimos então que, se não houvesse resistência por parte dos latifundiários pecuaristas e das oligarquias do Norte, os cafeicultores paulistas, que tinham instrumentalizado o Estado, continuariam com a emigração subsidiada

\footnotetext{
${ }^{43}$ Esses números podem ser encontrados nas obras já citadas de Girão (2000) e Frota (1985).

${ }^{44}$ FURTADO, op. cit., p. 191.

${ }^{45}$ FAORO, op. cit., p. 531.
} 
dos retirantes, e, salvo nos enganamos, teria resolvido o problema da mão de obra com os trabalhadores nacionais. Mas, como a classe dos cafeicultores já tinha estruturado a política imigratória às expensas do Estado, para o seu beneficiamento, não valeria a pena continuar essa desinteligência com as oligarquias do Norte que, embora mais fracas, exerciam grande influência sob a unidade federada.

Portanto, a questão de resolver a falta de trabalhadores no Sul com o braço nacional não aconteceu por causa do racismo que era tão peculiar à época, mas sim por causa da tensão política gerada entre o Norte semiárido e o governo central (ou Sul cafeicultor).

Antes de concluir, advertimos, mais uma vez, que o ato de ocultar a emigração dos sertanejos para o Sul no século XIX tem sido mantido por parte da historiografia e das ciências sociais, que continuam reproduzindo narrativas que engendram uma identidade paulista calcada somente na cultura estrangeira, europeia.

\section{Referências}

ARANHA, Graça. Canaã. Rio de Janeiro: Nova Fronteira, 1981.

BARREIRA, César. Trilhas e atalhos do poder. Rio de Janeiro: Rio Fundo, 1992.

BRAGA NETO, Edgar. Emigração cearense (1888-1915): sentidos, controle e configuração social. Saarbrücken, Germany: Novas Edições Acadêmicas, 2014.

BRASIL. Secretaria de Agricultura. Telegrama destinado ao Governo da Província do Ceará. Rio de Janeiro, 1888.

- Inspetoria de Obras Contra as Secas. Relatório dos trabalhos executados durante o anno de 1913. Imprensa Nacional: Rio de Janeiro, 1914.

CARONE, Edgard. A República Velha I: instituições e classes sociais (1889-1930). $4^{\mathrm{a}}$ edição, São Paulo: Difel, 1978.

. A República Velha II: evolução política (1889-1930). 3ª edição. São Paulo: Difel, 1977.

CARVALHO, José Murilo de. Os bestializados: O Rio de Janeiro e a República que não foi. São Paulo, Companhia das Letras, 1987.

CEARÁ. Secretaria de Governo. Relação de emigrantes Norte-Sul. Fortaleza, 1889. 
- Mensagem do presidente do Ceará Henrique D’Ávila dirigida à Assembleia Legislativa do Ceará. Fortaleza, 1889. - Mensagem do Presidente do Ceará Pedro Augusto Borges dirigida à Assembleia Legislativa do Ceará. Fortaleza, 1901.

COSTA, Emília Viotti. Da Monarquia à República: momentos decisivos. 9ª edição. São Paulo: Editora Unesp, 2010.

DAVIS, Mike. Holocaustos coloniais. [Tradução Alda Porto]. Rio de Janeiro: Record, 2002 .

DIAS, Arthur. Ceará. (Do livro O Brasil Actual 1904). Revista do Instituto do Ceará, t. XXVII, ano XXVII, 1913.

EISENBERG, Peter L. Homens esquecidos: escravos e trabalhadores livres no Brasil, século XVIII e XIX. Campinas: Ed. Unicamp, 1989.

ELIAS, Norbert; SCOTSON, John L. Os estabelecidos e os outsiders: sociologia das relações de poder a partir de uma pequena comunidade. [Tradução Vera Ribeiro]. Rio de Janeiro: Jorge Zahar Ed., 2000.

FAORO, Raymundo. Os donos do poder: formação do patronato brasileiro. $4^{\mathrm{a}}$ ed. São Paulo: Globo, 2008.

FROTA, Luciara Silveira de Aragão e. Documentação oral e temática da seca: estudos. Brasília: Centro Gráfico, Senado Federal, 1985.

FURTADO, Celso. Formação econômica do Brasil. São Paulo: Companhia das Letras, 2009. GIRÃO, Raimundo. História Econômica do Ceará. $2^{a}$ ed. Fortaleza: Casa José de Alencar, 2000 .

GONÇALVES, Paulo Cesar. Migração e mão de obra: retirantes cearenses na economia cafeeira do Centro-Sul (1877-1901). São Paulo: Editora Humanitas, 2006.

GUANABARA, Alcindo. A presidência Campos Sales. Brasília: Senado Federal, 2002.

HASENBALG, Carlos. Discriminação e desigualdades raciais no Brasil. $2^{\text {a }}$ edição. Belo Horizonte: Editora UFMG; Rio de Janeiro: IUPERG, 2005.

HOLLOWAY, Thomas H. Imigrantes para o café e sociedade em São Paulo. [Tradução Eglê Malheiros]. Rio de Janeiro: Paz e Terra, 1984. 
KIDDER, Daniel P. Reminiscências de viagens e permanência nas províncias do norte do Brasil: compreendo notícias históricas e geográficas do império e de diversas províncias. Belo Horizonte: Ed. Itatiaia; SP: USP, 1980.

LEAL, Victor Nunes. Coronelismo, enxada e voto: o município e o regime representativo no Brasil. 7ª edição. São Paulo: Companhia das Letras, 2002.

MORALES, Lúcia Arrais. Vai e vem, vira e volta: as rotas dos soldados da borracha. São Paulo: Annablume; Fortaleza: SECULT, 2002.

MOURA, Denise Aparecida Soares da. Saindo das sombras: homens livres no declínio do escravismo. Campinas: Unicamp, 1998.

PAIVA, Oldair da Cruz; MOURA, Soraya. Hospedaria de imigrantes de São Paulo. São Paulo: Paz e Terra, 2008.

SOBRINHO, Thomaz Pompeu. O Problema das Sêcas no Ceará. $2^{\text {a }}$ edição, Editores Gadelha S. Filho, 1920. . História das Secas (Século XX). Fortaleza: Ed. Batista Fontenelle, 1953.

SOUZA, Laura de Mello e. Desclassificados do ouro: a pobreza mineira no século XVII. 3 edição, 1986.

TEÓFILO, Rodolfo. História da Secca do Ceará (1877 a 1880). Fortaleza: Typographia do Libertador, 1883.

Artigo recebido para publicação em 08/06/2020

Artigo aprovado para publicação em 17/09/2020 